MARCELO EDUARDO GIACAGLIA

\title{
MODELAGEM DE DADOS PARA PLANEJAMENTO E GESTÃO OPERACIONAL DE TRANSPORTES
}

Trabalho apresentado à Escola Politécnica da Universidade de São Paulo para obtenção do título de Doutor em Engenharia 
MARCELO EDUARDO GIACAGLIA

\section{MODELAGEM DE DADOS PARA PLANEJAMENTO E GESTÃO OPERACIONAL DE TRANSPORTES}

Trabalho apresentado à Escola Politécnica da Universidade de São Paulo para obtenção do título de Doutor em Engenharia

Área de Concentração:

Engenharia de Transportes

Orientador:

Prof. Dr. Nicolau D. Fares Gualda

São Paulo

1998 
FICHA CATALOGRÁFICA

Giacaglia, Marcelo Eduardo.

Modelagem de Dados para Planejamento e Gestão Operacional de Transportes. São Paulo, 1998.

238 p. + apêndices

Tese (Doutorado) - Escola Politécnica da Universidade de São Paulo. Departamento de Engenharia de Transportes.

1. Planejamento de Transportes 2. Modelagem de Dados 3. Bancos de Dados I.

Universidade de São Paulo. Escola Politécnica. Departamento de Engenharia de Transportes II.t 


\section{AGRADECIMENTOS}

Ao orientador Prof. Dr. Nicolau D. Fares Gualda pelo apoio e incentivo recebido ao longo do desenvolvimento deste trabalho.

Às empresas Setepla Tecnometal Engenharia Ltda., SPTrans - São Paulo Transportes S.A. e The MVA Consultancy pelas informações fornecidas.

À minha esposa Marcella e filhas Alessandra e Luciana pela compreensão demonstrada durante a execução deste trabalho.

À CAPES pela ajuda financeira. 


\section{Lista de Tabelas}

Tabela 5.1- Principais Elementos e Indicadores utilizados pela

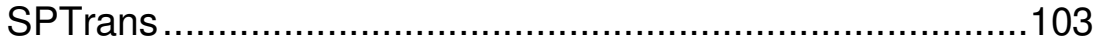

Tabela 5.2 - Número de Assaltos por Ano em ônibus do sistema sob gestão da SPTrans ………...............................................104 


\section{Lista de Figuras}

Figura 1.1 - Integração Interinstitucional em Transportes Urbanos ............. 4

Figura 1.2 - Integração Interinstitucional e Intra-institucional em

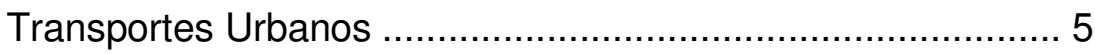

Figura 1.3 - Compartilhamento de Dados no âmbito Interinstitucional em Transportes Urbanos ................................................... 8

Figura 1.4- Compartilhamento de Dados nos âmbitos Interinstitucional e Intra-institucional em Transportes

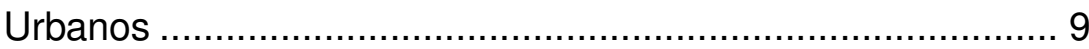

Figura 2.1 - MOR parcial para o exemplo de aplicação bancária ...............21

Figura 2.2 - Seqüências de Integração de Sistemas pela Abordagem

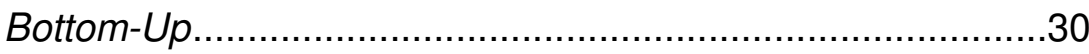

Figura 4.1 - Tratamento da dimensão tempo: exemplo para o Modelo

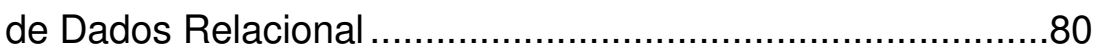

Figura 4.2 - MOR (parcial) do Caso Exemplo..........................................87

Figura 5.1 - Parte de um possível Data Warehouse para a SPTrans......108

Figura 5.2 - Dimensional Data Warehouse integrado ao Sistema

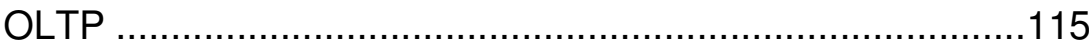

Figura 6.1 - Unidades Residenciais, Domicílios e Indivíduos ..................144

Figura 6.2 - Tipo de Atividade, Localização, Cenário, Base e Motivo......145

Figura 6.3 - Sistemas de Zoneamento e Zonas .....................................148

Figura 6.4 - Modos de Transporte para a RMSP .....................................149

Figura 6.5 - Redes de Transporte e Ligações ……………………….....151

Figura 6.6 - Oferta de Transporte Coletivo ………………………….....152

Figura 6.7 - Tarifas de Transporte Coletivo Público .................................153 
Figura 6.8 - Viagens por Unidade Pesquisada ……………………......155

Figura 6.9 - Viagens agregadas por Zona .............................................157

Figura 6.10 - Fluxos nas Ligações ........................................................158

Figura 7.1 - Arquitetura de Esquemas de um SMBD .............................184

Figura 7.2 - Processamento de Consultas em um SMBD ........................185

Figura 7.3 - Arquitetura de Esquemas de um SMBD como o UniSQL/M ...............................................................18 


\section{RESUMO}

A integração das atividades da gestão de sistemas de transportes urbanos, em todos os níveis, é altamente desejável no âmbito de uma entidade. A integração interinstitucional é também importante quando existe sobreposição de planos ou de áreas de atuação, situação típica de grandes aglomerados urbanos.

Para que os planos dessas entidades sejam consistentes entre si, há necessidade do uso compartilhado de informações. Esse compartilhamento é melhor obtido pela integração dos respectivos bancos de dados. Tal integração, entretanto, tem sido inviabilizada por fatores de natureza técnica e até política ligadas à necessária autonomia de cada uma.

Nesta Tese, após a análise de diversas tentativas de solução para o problema, são identificados os aspectos críticos para a modelagem e a construção de Sistemas de Bancos de Dados, como elementos de suporte à Integração do Planejamento e da Gestão Operacional de Transportes, tanto no âmbito intra-institucional como interinstitucional. Para cada um deles, são indicadas as deficiências de sistemas existentes e propostas soluções ou diretrizes.

Os aspectos críticos identificados e tratados são:

- a capacidade de suporte à integração das diferentes atividades da gestão operacional: planejamento, programação e acompanhamento, em uma mesma entidade;

- a capacidade de suporte à integração dos diferentes níveis decisórios em uma mesma entidade;

- o conteúdo, a estrutura e a estabilidade temporal de bancos de dados utilizados em planejamento estratégico e/ou tático, regional e/ou local;

- a capacidade de prover a comunicação interinstitucional;

- a estabilidade face a mudanças institucionais. 


\begin{abstract}
The integration of urban transportation systems management activities, at all levels, pertaining one entity, is highly desirable. Integration across entities is also important when their plans or transportation systems overlap, as usually happens in urban agglomerations.

In order to achieve consistent plans among these entities, information must be shared. This sharing of information is better obtained through the integration of their databases. However, such integration has been unsuccessful because of technical and even political factors related to the necessary autonomy of each one.

In this Thesis, after analysing several attempts to solve the problem, critical aspects of modelling and building database systems to support Integrated Transportation Planning and Management, pertaining to one entity and also across multiple entities, are identified. For each one, deficiencies of existing systems are analysed and solutions are proposed or directions to follow are given.
\end{abstract}

The critical aspects identified and dealt with are:

- the ability to support the integration of the different transportation management activities at the operational level: planning, programming and attendance, pertaining one entity;

- the ability to support the integration of different decision levels pertaining one entity

- the content, structure and the temporal stability of databases used for planning at the strategic and/or tactical and regional and/or local levels;

- the ability to provide communication among different entities;

- the stability in the face of institutional changes. 